\title{
KERUKUNAN ANTAR UMAT BERAGAMA PERSPEKTIF AL-QUR'AN DAN AL-HADITH
}

\author{
Aceng Zakaria
}

\author{
Dosen Prodi IAT STAI Al Hidayah Bogor \\ Email : abo.azka@yahoo.co.id
}

\begin{abstract}
Abstrak
Tulisan ini mendiskusikan tentang hubungan antara agama Islam dengan agama lainnya. Selain itu, tulisan ini juga menawarkan konsep kerukunan antar umat beragama yang dewasa ini mulai memudar. Islam sebagai agama wahyu telah dengan sangat komprehensif menjelaskan dan memberikan rambu-rambu kepada pemeluknya dalam berinteraksi kehidupan beragama dengan umat lainnya. Hal ini tentu sangat sejalan dengan visi misi Islam yang dibawa oleh Nabi Muhammad sebagai agama rahmatan lil 'alamin (rahmat bagi alam semesta).
\end{abstract}

Kata Kunci: Agama, Islam, kerukunan, dan rahmat.

\section{A. Pendahuluan}

Berbicara tentang kerukunan antar umat beragama di Indonesia khususnya maupun di dunia Islam pada umumnya, hingga muncul wacana penyamaan agama menjadi perbincangan yang menarik untuk dikaji. Pluralisme agama sendiri dimaknai secara berbeda-beda di kalangan cendekiawan Muslim Indonesia, baik secara sosiologis, teologis maupun historis. Indonesia selain merupakan negara dengan populasi umat Islam terbesar di dunia, juga dikenal sebagai negara yang mengakui keragaman pemeluk agama lainnya selain Islam. Oleh karena itu Indonesia menjadi barometer kerukunan antar umat beragama oleh bangsa-bangsa di dunia.

Secara sosiologis, pluralisme agama adalah suatu kenyataan bahwa kita adalah berbeda-beda, beragam dan plural dalam hal beragama. Ini adalah kenyataan sosial, sesuatu yang niscaya dan tidak dapat dipungkiri lagi keberadaannya. Dalam kenyataan sosial, kita telah memeluk agama yang berbeda-beda. Pengakuan terhadap adanya pluralisme agama secara sosiologis ini merupakan fakta pluralisme 
yang paling sederhana, karena pengakuan ini tidak berarti mengizinkan pengakuan terhadap kebenaran teologi atau bahkan etika dan norma dari agama lain.

Sejatinya kebenaran suatu agama itu bisa dilihat dan dipelajari dari kitab suci yang diyakininya. Apakah ia benar-benar wahyu Tuhan atau bukan. Boleh jadi pada mulanya ia benar dari Allah swt, namun kemudian dirombak (dirubah, ditambah) untuk disesuaikan dengan keyakinan dan filsafat tertentu atau untuk tujuan politik ataupun hal lainnya pada masa tertentu.

Konsep agama dan kitabnya evolutif (berubah), yang berkembang dan berubah dari waktu kewaktu, sama sekali tidak tepat diterapkan untuk Islam, karena Islam adalah agama yang sudah sempurna sejak awal hingga kini dan tidak tunduk oleh perubahan dan keadaan. Kenyataan ini telah Allah tetapkan dalam firman-Nya:

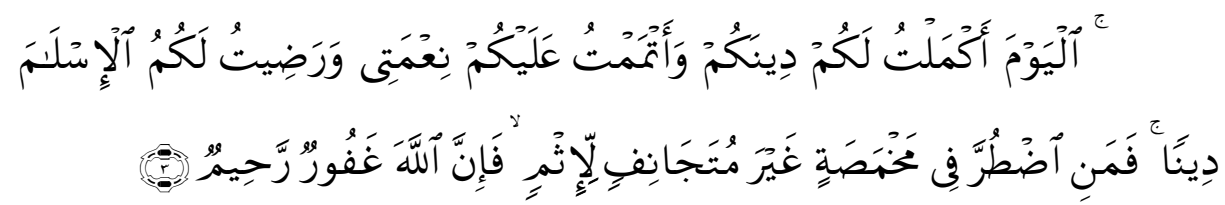

Pada hari ini telah Kusempurnakan untuk kamu agamamu, dan telah Ku-cukupkan kepadamu nikmat-Ku, dan telah Ku-ridhai Islam itu Jadi agama bagimu. Maka barang siapa terpaksa karena kelaparan tanpa sengaja berbuat dosa, Sesungguhnya Allah Maha Pengampun lagi Maha Penyayang.(QS. al Maidah: 3)

Ayat di atas dengan sangat jelas disebutkan bahwa ajaran Islam telah sempurna sehingga tidak membutuhkan penambahan-penambahan ataupun pengurangan dari berbagai sisinya. Kesempurnaan agama Islam dikarenakan datang dari Dhat yang Maha sempurna. Inilah keyakinan yang menghujam dalam dada-dada orang beriman.

\section{B. Hubungan Antar Agama Dalam Sejarah}

Islam adalah agama yang lurus (al-Shirathal al-Mutakim), agama yang sesuai dengan fitrah manusia. Ajarannya senantiasa memberikan kebaikan bagi setiap insan yang percaya kepada kebenaran, menjadi rahmat bagi semesta alam. Memberiakan jaminan 
ketenangan lahir dan batin, serta menjanjikan keselamatan dunia dan akhirat.

Sejarah mencatat, bahwa kehadiran Nabi Muhammad dan Islam ke Madinah telah memberikan banyak pelajaran yang sangat berharga bagi perjalanan umat manusia dan juga bagi kehidupan beragama. Seorang orientalis kenamaan John L. Esposito ${ }^{126}$ menyebutkan bahwa ketika Nabi Muhammad datang ke Madinah beliau sebagai arbitan atau hakim bagi seluruh komunitas, baik yang muslim maupun non muslim. Hal demikian bukan tanpa alasan, karena Nabi Muhammad diutus tidak hanya memberikan perlindungan kepada kaumnya saja melainkan kepada semua kalangan termasuk kaum Yahudi yang ada di Madinah. Bahkan mereka tetap menjadi minoritas penting di masa-masa awal pertumbuhan Islam. ${ }^{127}$

Pada tahap selanjutnya, minoritas Yahudi diberikan payung hukum yang menjamin mereka tetap eksis sebagai bagian komunitas yang dijamin oleh konsitusi legal yang diatur dan dirumuskan oleh Rasululullah. Konsitusi ini kemudian dikenal dengan Piagam Madinah atau konsitusi Madinah. Dalam konsitusi tersebut diataur hak dan kewajiban seluruh warga negara dan juga mengatur hubungan antar ummah (komunitas Muslim) dengan komunitas-komunitas lainnya. Kaum Muslim merupakan ummah yang identitas dan keterikatan utamanya tidak lagi ikatan-ikatan kesukuan tetapi iman agama dan komitmen bersama. Kaum Yahudi diakui sebagai suatu komunitas terpisah yang bersekutu dengan ummah muslimin, namun dengan otonomi agama dan budaya. ${ }^{128}$

Selanjutnya Esposito menjelaskan gambaran dan kondisi masyarakat Madinah di bawah kepemimpinan Nabi Muhammad kala itu dengan mengatakan:

"Meski mengakui perbedaan-perbedaan dalam hal status, kekayaan, dan asal-usul, al-Qur'an mengajarkan kesatuan dan kesetaraan tertinggi supra-suku (transnasional) dari semua orang

${ }^{126}$ Guru besar Agama dan hubungan Internasional George town Universisity (GU) AS, dan Direktur Center for Muslim-Chistian Understanding, GU

${ }^{127}$ Lihat John L. Esposito, Islam: The Straight Path, Islam Warna Warni: Ragam Ekspresi Menuju “Jalan Lurus”, Arif Maftuhin, (Jakarta: Paramadina, 2004), Cet. I. 14.

${ }^{128}$ Lihat John L. Esposito, Islam: The Straight Path, Edisi Indonesia Islam Warna Warni: Ragam Ekspresi Menuju "Jalan Lurus", Penerjemah: Arif Maftuhin, (Jakarta: Paramadina, 2004), Cet. I. 16 
beriman di hadapan Tuhan. Bukan ikatan-ikatan kesukuan atau keluarga, mengikat masyarakat keseluruhan. Al-Qur'an menginginkan suatu masyarakat yang berdasarkan pada kesatuan dan kesetaraan orang-orang beriman, sebuah masyarakat tempat tempat keadilan moral dan sosial akan mengimbangi penindasan kaum lemah dan eksploitasi ekonomi" ${ }^{\prime 29}$

Bernand Lewis ${ }^{130}$ menjelaskan tentang hubungan muslim dan non muslim dalam suatu negara yang dipimpin oleh penguasa Muslim yaitu Nabi Muhammad di masa awal perkembangan Islam kala itu bisa dilihat dari komposisi penduduk kota Madinah yang heterogen. Lewis menyebutkan sedikitnya ada tiga agama besar tumbuh dan bekembang di Madinah, yaitu Islam, Yahudi, dan Nasrani, bahkan ada dari masyarakat Madinah waktu itu yang berpaham paganisme (penyembah berhala) dan Majusi (penyembah api). Mereka tersebar di sekitar Madinah $^{131}$ dan mereka diberikan kebebasan oleh Islam untuk hidup normal tanpa mendapat tekakanan dan gangguan atau paksaan untuk memeluk Islam.

Apa yang dikemukakan Esposito dan Lewis di atas sepintas dapat ditarik benang merah bahwa secara historis Islam yang dibawa oleh Nabi Muhammad dapat diterima di kalangan masyarakat yang multikultural. Hal ini menjadi bukti akan keselarasan ajaran Islam dengan fitrah manusia yang menghendaki hidup damai dan tentram tanpa ada penindasan pihak mayoritas terhadap minoritas juga tidak menghendaki permususuhan antar umat beragama.

Sedangkan menurut Adian Husaini, perbedaan konsepsi di antara agama-agama yang ada adalah sebuah realitas, satu kenyataan yang tidak dapat dipungkiri oleh siapapun. ${ }^{132}$ Perbedaan, bahkan benturan konsepsi itu terjadi pada hampir semua aspek dalam agama, baik dalam bidang konsepsi Tuhan maupun konsepsi sistem pengaturan kehidupan dan lainnya.

\footnotetext{
${ }^{129}$ John L. Esposito, Islam: The Straight Path, Edisi Indonesia Islam Warna Warni: Ragam Ekspresi Menuju “Jalan Lurus”, Penerjemah: Arif Maftuhin, (Jakarta: Paramadina, 2004), Cet. I. h. 39.

${ }^{130}$ Lihat Bernand Lewis,The Jews of Islam, Edidsi Indonesia, Yahudi-Yahudi Islam, Penerjemah: M. Sadat Ismail, (Jakarta: Nizam Press, 2001), Cet. I. h. 12.

${ }^{131}$ Kebanyakan kaum Yahudi berdomisili di Madinah dan Hijaz utara sedangkan kaum Nasrani Najran banyak tinggal di wilayah selatan Madinah.

132 Adian Husaini, Tinjauan Historis Konflik Yahudi, Kristen, Islam, (Jakarta: GIP, 2004), Cet. I,1.
} 
Sejak munculnya manusia di muka bumi ini, mulailah perbedaan itu muncul. Manusia dikaruniai Tuhan berupa akal dengan kadar kemampuan dan jenis serta jumlah informasi yang berbeda antar satu dengan yang lainnya, sehingga sangat memungkinkan dalam memahami sesuatu akan berbeda pula. Di mana hal itu merupakan proses alami dalam kehidupan manusia. Sumber-sumber informasi yang dialami manusia juga berbeda, belum lagi sikap apriori dan fanatisme dengan berbagai faktornya yang juga menjadi penyebab munculnya pebedaan pandangan dan sikap.

Masih menurut Adian, perbedaan pendapat dan konsepsi keagamaan tidaklah otomatis memunculkan konflik pada level praktis. Bahkan sepanjang sejarah, kehidupan damai dan harmonis lebih banyak dijalani umat beragama, dibandingkan periode-periode konfilik keagamaan. Sepanjang konflik Islam dan Kristen yang terkenal dengan perang salib yang berlangsung selama ratusan tahun, misalnya, banyak sekali ditemukan hubungan sosial Islam dan Kristen di wilayah Syiria. $^{133}$

Semua manusia tanpa terkecuali dilihat dari segi bentuk kejadiannya adalah sama, bapak mereka adalah dari Nabi Adam dan ibu beasal dari Hawa. Dari mereka berdua Allah kemudian kembangbiakan keturunan sampai hari kiamat. ${ }^{134}$ Adapun tujuan Allah menciptakan manusia yaitu untuk mentauhidkan-Nya dalam beribadah. Meski demikian sunnah kauniyyah menunjukan tidak semua manusia tidak berada pada satu agama yang diridhai-Nya.

\section{Hubungan Antar Agama dalam Pandangan Cendekiawan}

Mukti Ali menjelaskan bahwa ada beberapa pemikiran diajukan orang untuk untuk mencapai kerukunan dalam kehidupan beragama. Pertama, sinkretisme, yaitu pendapat yang menyatakan semua agama adalah sama. Kedua, reconception, yaitu menyelamai dan meninjau kembali agama sendiri dalam konfrontasi dengan agama-agama lain. Ketiga, sintesis, yaitu menciptakan suatu agama baru yang elemenelemenya diambilkan dari pelbagai agama, supaya dengan demikian

133 Adian Husaini, Tinjauan Historis Konflik Yahudi, Kristen, Islam, (Jakarta: GIP, 2004), Cet. I,1.

${ }^{134}$ Abdul Hamid Kisyk, Dialog Haq dan Bathil, (Solo: Pustaka Mantiq, 1992), Cet. II, 49. 
tiap-tiap pemeluk agama merasa bahwa sebagian dari ajaran agamanya telah terambil dalam agama sintesis (campuran) itu. Keempat, penggantian, yaitu mengakui bahwa gamanya sendiri itulah yang benar, sedangkan agama lainnya salah dan berusaha supaya orang-orang yang berbeda agama masuk ke dalam agamanya. Kelima, agree in disagreement (setuju dalam perbedaan), yaitu percaya bahwa agama yang dipeluk itulah agama yang paling baik dan mempersilahkan orang lain untuk mempercayai bahwa agama yang dipeluknya adalah agama yang palin baik pula. Diyakini bahwa antara agama dan agama lainnya, selain terdapat perbedaan, juga terdapat persamaan. ${ }^{135}$

Wacana pluralisme agama, Djohan Efendi berbeda dengan Mukti Ali di atas. Dimana pengakuan pluralisme Djohan Efendi bukan hanya pengakuan secara sosiologis bahwa umat beragama berbeda, tetapi juga pengakuan tentang titik temu secara teologis di antara umat beragama. Djohan tidak setuju dengan absolutisme agama. Ia membedakan antara agama itu sendiri dengan keberagamaan manusia. Pengertian antara agama dan keberagamaan harus difahami secara proposional. Menurutnya, agama-terutama yang bersumber dari wahyu, diyakini sebagai bersifat ilahiyah. Agama memiliki nilai mutlak, namun ketika agama itu dipahami oleh manusia, maka kebenaran agama itu tidak bisa sepenuhnya ditangkap dan dijangkau oleh manusia, karena manusisa sendiri bersifat nisbi. Oleh karena itu, kebenaran apapun yang dikemukakan oleh manusia termasuk kebenaran agama yang dikatakan oleh manusia bersifat nisbi, tidak absolut. Yang absolut adalah kebenara agama itu sendiri, sementara kebenaran agama yang dikatakan oleh manusia itu nisbi. Kebenran absolut itu hanya bisa dikethui oleh ilmu Tuhan. ${ }^{136}$

Greg Barton menyebutkan bahwa Djohan Efendi menolak absolutisme agama dan mengakui pluralisme agama..

Djohan mengemukakan"

${ }^{135}$ A. Mukti Ali, Ilmu Perbandingan Agama, Dialog , Dakwah dan Misi, dalam Burhanudin Daja dan Herman Leonard Beck, Ilmu Perbandingan Agama di Indonesia dan Belanda, (Jakarta: INIS 1992), h. 227-229.

${ }^{136}$ Djohan Efendi, Dialog Antar Agama: Bisakah Melahirkan Teologi Kerukunan? Dalam Majalah Prisma 5, Juni 1978, h. 16. Lihat juga Djohan Efendi, Kemusliman dan Kemajemukan Agama, dalam Th. Sumarthana dkk, Dialog: Kritik dan Identitas Agama, h. 54-58 
"Sebagai makhluk yang bersifat nisbi, pengertian dan pengetahuan manusia tidak mungkin mampu menjangkau dan menagkap agama sebagai doktrin kebenaran secara tepat dan menyeluruh. Hal itu hanya ada dalam ilmu Tuhan. Dengan demikian apabila seseorang penganut agama mengatakan perkataan agama, yang ada dalam pikirannya bukan hanya agama sendiri, akan tetapi juga aliran yang dianutnya, bahkan pengertian dan pemahammannya sendiri. Oleh karena itu, pengertian dan pemahamannya tentang agama jelas bukan agama itu sendiri dan karena itu tidak ada alasan untuk secara mutlak dan a priori menyalahkan pengeertian dan pemahaman orang lain. ${ }^{137}$

Hal yang sama juga dikemukakan oleh Nurkholish Majid. Ia mengemukakan ketidaksetujuannya dengan absolutisme, karena absolutisme adalah pangkal dari permusuhan. Ia mengatakan :

"Petunjuk konkret lain untuk memelihara ukhuwah adalah tidak dibenarkannya sama sekali suatu kelompok dari kalangan orang-orang beriman untuk memandang rendah atau kurang menghargai kelompok lainnya, sebab siapa tahu mereka yang dipandang rendah itu lebih baik dari pada mereka yang memandang rendah.. Hal ini mengajarkan kita dalam pergaulan dengan sesama manusia, khususnya sesama kalangan yang percaya kepada Tuhan untuk tidak melakukan absolutisme, suatu pangkal dari segala permusuhan". ${ }^{138}$

Merujuk pada kitab suci al-Qur'an, Nurcholis menegaskan bahwa setiap umat atau golongan manusia telah pernah dibangkitkan atau diutus seorang utusan Tuhan, dengan membawa tugas yaitu menyeru umatnya untuk menyembah Tuhan saja (dalam) pengertian paham Ketuhanan Yang Maha Esa) yang murni). Kemudian Ia mengutip surat al-Nahl (16): 36. Berdasar firman Allah tersebut tersebut Nurcholis mengatakan bahwa:

“...semua agama Nabi dan Rasul yang telah dibangkitkan dalam setiap umat adalah sama, dan inti dari semua ajaran Nabi dan Rasul itu

${ }^{137}$ Lihat Greg Barton, Gagasan Islam Liberal di Indonesia: Pemikirran Neomodernisme Nurcholish Majid, Djohan Efendi, Ahmad Wahib, dan Abdurrahman Wahid, pent. Nanang Tahqiq, (Jakarta: Paramadina, 1999), cet. I, h. 237.

138 Paragraf tersebut merupakan komentar Nurcholish Majid yang dicantumkan dalam buku Atas Nama Agama. Lihat Andito, Atas Nama Agama: Wacana Agama dalam Dialog 'Bebas' Konflik, (Bandung: Pustaka Hidayah, 1998), h. 259. 
ialah Ketuhanan Yang Maha Esa dan perlawanan terhadap kekuatankekuatan tiranik. Denga perkataan lain, Ketuhanan Yang Maha Esa dan perlawanan terhadap tirani adalah titik pertemuan, common platform atau dalam bahasa al-Qur'an, disebut kalimatun sawa (kalimat atau ajaran yang sama) antara semua kitab suci". ${ }^{139}$

Apa yang dikemukakan Nurcholis di atas sepintas tidak ada yang ganjil, namun ika dikaji ada hal yang yang tendensius dan sangat membahyakan aqidah bagi siapapun yang membenarkan ucapannya tentang kalimat sawa (ajaran yang sama) antara semua penganut kitab suci, sebagaimana dipahami oleh Nurcholis. Padahal makna yang yang benar adalah para nabi dan rasul diutus untuk menyeru manusia ke dalam tauhid (pengesaan) dan Islam (kepasrahan dan ketundukan) hanya kepada Allah yang Esa bukan yang lainnya serta tidak menyekutukan dalam beribadah kepada-Nya. Cara beragama inilah yang dilakukan oleh Rasulullah dan para sahabatnya di masa awal kemunculan Islam di Mekah dan Madinah.

\section{Agama Para Nabi Adalah Islam}

Hakikat agama para nabi adalah menyembah Tuhan seluruh alam. Inilah hakikat yang disepakati oleh para nabi dan Rasul, meskipun mereka memiliki syari'ah dan manhaj yang yang berbeda antar satu dan yang lainnya Meskipun syari'ah dan manhaj mereka berbeda, tetapi agama mereka adalah satu yaitu Islam. ${ }^{140}$

Sedangkan makna Islam secara khusus sebagaimana dikemukakan oleh Shaleh Abdul Aziz ${ }^{141}$ memiliki beberapa makna di antaranya; pertama, Islam umum, yaitu agama para nabi dan rasul. Kedua, Islam khusus, yaitu Islam yang dibawa oleh Nabi Muhammad. Ketiga, Islam yang lebih khusus, yaitu bersaksi bahwa tidak ada Tuhan

\footnotetext{
${ }^{139}$ Lihat Nurcholis Majid, Beberapa Renungan tentang Kehidupan Keagamaan untuk Generasi Mendatang, dalam Jurnal Ulum al-Qur'an, No. 1, Vol. IV, Th. 1993, h. 12

${ }^{140}$ Artinya agama Islam yang bersifat umum, yaitu agama yang dibawa oleh para Rasul adalah Islam yang poros dari ajaran mereka adalah penyerahan diri kepada Allah swt dengan mentauhidkan-Nya, tunduk patuh kepada-Nya, menta'atiNya dan berlepas diri dari syirik dan pelakunya.

${ }^{141}$ Lihat Shaleh Abdul Aziz, Syarah Kitab al-Furqan Baina Auliya alRahman wa Auliya al-Syaithan, edisi Indonesia: Catatan-catatan Ibnu Taimiyah Menembus Batas kewalian, Penerjemah: Azhar Khalid, (Jakarta: Akbar, 2008), Cet. I, h. 214.
} 
melainkan Allah dan Muhammad adalah utusan Allah, mengerjkan shalat, membayar zakat, berpuasa di bulan Ramadhan, dan berhaji jika mampu. ${ }^{142}$ Hal senada juga disampaikan oleh Ahmad Hakami. ${ }^{13}$

Syaikh Bakr bin Abdullah Abu Zaid ${ }^{144}$ dalam sebuah risalahnya yang berjudul "Ibthal Nadzariyah al-Khalath Bainal Islam wa Ghairihi minal Adyan". ${ }^{145}$ Menurut pandangan beliau agama seluruh para nabi dan rasul adalah satu yaitu Islam. Dan Allah telah mengutus mereka dari Adam sampai nabi terakhir Muhammad 烸 juga dengan agama tesebut. Dakwah mereka satu dan agama merekapun satu. Sedangkan yang berbeda adalah masalah syari'at-syari'at yang menjadi cabang agama itu.

Para nabi diutus dengan agama yang sama dan seruan mereka juga sama yaitu mengajak manusia untuk hanya menyembah Allah semata yang tidak ada sekutu bagi-Nya. Allah Ta'ala berfirman dalam al-Qur'an surat an-Nahl ayat 36:

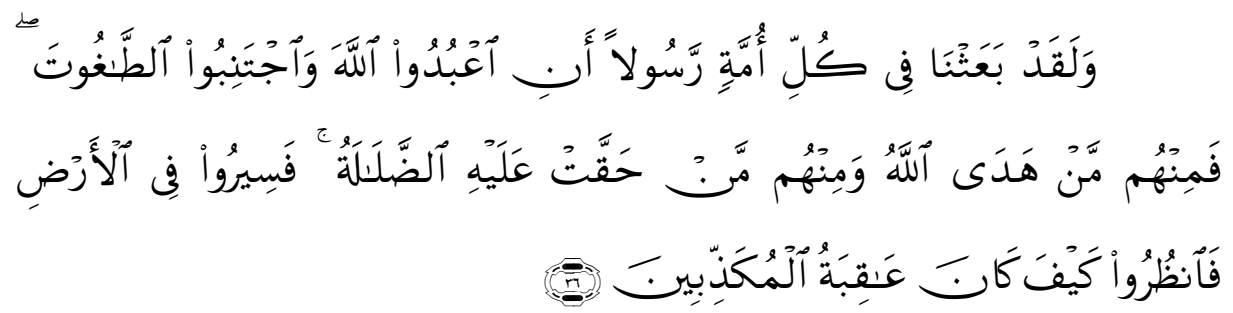

"dan sungguhnya Kami telah mengutus Rasul pada tiap-tiap umat (untuk menyerukan): "Sembahlah Allah (saja), dan jauhilah Thaghut itu", Maka di antara umat itu ada orang-orang yang diberi petunjuk oleh Allah dan ada pula di antaranya orang-orang yang telah pasti kesesatan baginya. Maka berjalanlah kamu dimuka bumi dan perhatikanlah bagaimana kesudahan orang-orang yang mendustakan (rasul-rasul).

\footnotetext{
${ }^{142}$ Shaleh Abdul Aziz, Syarah Kitab al-Furqan Baina Auliya al-Rahman wa Auliya al-Syaithan, h. 214.

143 Lihat Ahmad Hakami, 200 Su'al wa al-Jawab Fil al-'Aqidati alIslamiyyah, Edisi Indonesia, 222 Kunci Akidah yang Lurus, Penerjemah: Moh. Asror Yusuf, (Jakarta: Mustaqim, 2004), Cet. II. h. 32.

144 Seorang ulama kontemporer asal Nejd, KSA, juga seorang penulis produktif dalam berbagai disiplin ilmu, di antaranya, Fiqh al-Qodhayaa al-Mu'asirah (Fiqh Nawazil) 3 jilid, Risalah at-Taqniin, Hilyah Thalib al-Ilm, dan lain-lain.

${ }^{145}$ Tulisan Syekh Bakr bin Abdullah Abu Zaid yang secara khusus untuk membantah paham sesat pluralisme agama yang marak di dunia Islam.
} 
Untuk beribadah kepada Allah dan untuk mencapai keridhoanNya, Allah hanya menurunkan satu agama kepada hamba-hamba-Nya, sejak awal penciptaan manusia hingga hari kiamat kelak, yaitu Islam. Seluruh nabi, dari Adam sampai Nabi Muhammad hanya membawa dan mendakwahkan agama Islam. ${ }^{146}$

Perjalanan Islam sampai saat telah mengalami berbagai penyimpangan yang dilakukan oleh umatnya. Di antara banyaknya penyimpangan tersebut yang paling besar adalah apa yang dilakukan oleh pengikut nabi Musa dan nabi Isa. Kedua pengikut nabi yang mulia tersebut dikenal dengan Yahudi dan Nasrani. Umat Islam yang awam menganggap bahwa nabi Musa diutus dengan membawa agama Yahudi dan nabi Isa diutus dengan membawa agama Nasrani, sehingga sampai pada kesimpulan bahwa antara Islam, Yahudi dan Nasrani adalah samasama agama samawi yang diturunkan oleh Allah swt kepada manusia. Bahkan, ada yang lebih parah dari itu, sampai pada anggapan bahwa Islam, Yahudi dan Nasrani diibaratkan sebagai perbedaan madzhab saja, sebagaimana perbedaan madzhab dalam dalam bidang fiqih.

Padahal yang benar agama mereka adalah Islam, bukan Yahudi dan juga bukan Nasrani. Sedangkan Allah swt menyebut kedua pengikut nabi tersebut dalam al-Qur'an dengan 'Ahlul Kitab', seperti firman-Nya dalam surat Ali Imran ayat 64:

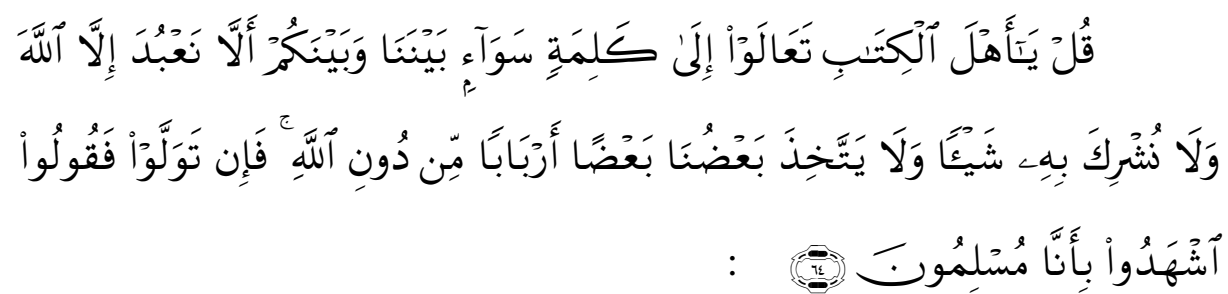

"Katakanlah: "Hai ahli Kitab, Marilah (berpegang) kepada suatu kalimat (ketetapan) yang tidak ada perselisihan antara Kami dan kamu, bahwa tidak kita sembah kecuali Allah dan tidak kita persekutukan Dia dengan sesuatupun dan tidak (pula) sebagian kita menjadikan sebagian yang lain sebagai Tuhan selain Allah". jika mereka berpaling Maka Katakanlah kepada mereka: "Saksikanlah, bahwa Kami adalah orang-orang yang berserah diri (kepada Allah)".

${ }^{146}$ Lajnah Ilmiyyah Hasmi, al-Shiratul al-Mustaqim, (Bogor: Putaka MIM, 2007), Cet. I, 15. 


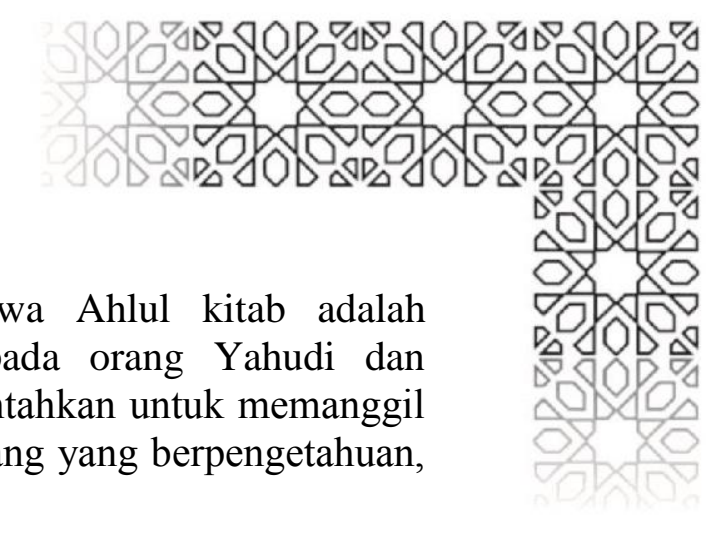

Yahudi bukanlah agama yang dibawa oleh Nabi Musa as. Banyak ayat al-Qur'an yang menjelaskan berbagai penyelewengan kaum Yahudi dari ajaran Nabi Musa. Kaum Yahudi juga tidak akan mau jika agamanya disebut sebagai 'Islam". Dan terlalu banyak perbedaan yang sangat mendasar antara Islam dan Yahudi. Hal demikian juga terjadi antara Islam dan Nasrani. ${ }^{149}$

Alhasil baik Yahudi maupun Nasrani bukanlah agama yang diturunkan Allah kepada manusia melainkan sebutan untuk pengikut nabi Musa dan Isa. Mereka tak layak disamakan dengan Islam karena mereka tidak bersandar kepada syari'at abadi yang diturunkan. Agama mereka adalah bathil dan sudah dirubah, atau benar tapi sudah dihapus oleh Islam.

Oleh karena itu, dalam terminologi al-Qur'an mereka disebut kafir, yakni "yang menentang", atau "yang menolak", dalam hal ini menentang atau menolak nabi Muhammad dan ajaran yang dibawanya yaitu ajaran Islam. Meskipun Nurcholis Majid berusaha mengaburkan konsep Ahli Kitab dengan meleburkan definisinya di luar kelompok Yahudi dan Nasrani, namun, Nurcholis tidak memasukkan mereka sebagai muslim. ${ }^{150}$

\section{E. Islam Menolak Paham Pluralisme}

Dewasa ini berkembang paham plurarisme agama ${ }^{151}$, gaung dari seruan ini sudah sampai kepada level yang membahayakan akidah umat

\footnotetext{
${ }^{147}$ Seorang fakar kristolog international berkebangsaan India.

${ }^{148}$ Lihat Ahmad Deedat dan Abdullah Wasian, dalam bukunya, Kata Bibel tentang Muhammad, (Jakarta: Pustaka Da'i, 1993), cet. II, 46.

${ }^{149}$ Adian Husaini, Virus Liberalisme di Perguruan Tinggi Islam, (Jakarta: Gema Insani Perss, 2009), Cet. I, 19.

150 Adian Husaini, Tinjauan Historis Konflik Yahudi, Kristen, Islam, (Jakarta: GIP, 2004), Cet. I,13.

151 Plurarisme adalah paham yang mentoleransi adanya keragaman pemikiran, peradaban, agama dan budaya. Bukan hanya menoleransi adanyaa keragaman pemahaman tersebut, tetapi bahkan mengakui kebenaran masing-masing
} 
Islam yang awam akan pemahaman Islam yang benar. Seruan untuk mencampuradukan agama Islam dengan agama-agama lain yang sesat seperti Yahudi dan Nasrani tersebut telah memakan banyak korban.

Slogan yang dikumandangkan oleh kaum kafirin seperti, pendekatan antar agama, penyatuan agama langit, persaudaraan antar agama atau dialog antar agama, tersebut juga telah merambah bukan hanya di kota-kota besar bahkan sudah sampai ke pelosok desa. Lagilagi korban dari seruan sesat tersebut tidak hanya kalangan awam tapi juga kalangan cendekiawan yang dangkal imannya. Realitas tersebut menunjukan bahwa pemikiran pluralisme semakin diterima secara luas di masyarakat. ${ }^{152}$

Nabi Muhammad dan umatnya dilarang keras oleh Allah swt mengikuti paham penyatuan agama-agama sebagaimana firman-Nya dalam surat al-Kafirun:

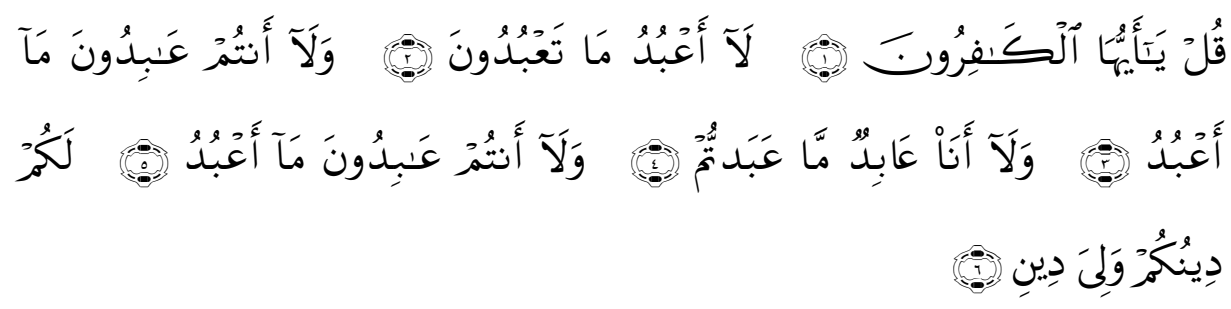

1. Katakanlah: "Hai orang-orang kafir,

2. aku tidak akan menyembah apa yang kamu sembah.

3. dan kamu bukan penyembah Tuhan yang aku sembah.

4. dan aku tidak pernah menjadi penyembah apa yang kamu sembah,

5. dan kamu tidak pernah (pula) menjadi penyembah Tuhan yang aku sembah.

6. untukmu agamamu, dan untukkulah, agamaku."

Ibnu Kathir (w. $774 \mathrm{H}$ ), menjelaskan tentang makna surat di atas dengan mengatakan, bahwa, surat ini merupakan perintah Allah

pemahaman. Secara khusus pluralisme meyakini bahwa semua agama itu adalah sama dan menuju kepada Tuhan yang sama.

$152 \mathrm{http} / / / \mathrm{www} . \mathrm{muslimdaily.net/artikel/studiislam/pluralisme-agama-dalam-}$ pandangan-islam.html. Diakses tanggal 20 Oktober 2017. 
kepada orang beriman untuk berlepas diri dari perbuatan orang-orang kafir di manapun mereka berada. ${ }^{153}$

Menurut al-Qurthubi ${ }^{154}$ ketika menafsirkan Surat al-Kafirun di atas beliau meringkasnya dengan menjelaskan:

"Katakanlah olehmu wahai utusanku, kepada kafir-kafir itu, bahwasanya aku tidaklah mau diajak menyembah berhala-berhala yang kamu sembah dan puja itu, kamu pun rupanya tidaklah mau menyembah Allah saja sebagaimana yang aku lakukan dan serukan. Malahan kepada Allah saja sebagaimana yang aku lakukan dan serukan. Maka kalau kamu katakan bahwa kamu pun menyembah Allah jua, perkataan itu bohong, karena kamu adalah musyrik. Sedangkan Allah itu tidak dapat dipersyaratkan dengan yang lain. Dan ibadat kita pun berlainan. Aku tidak menyembah kepada tuhanku sebagaimana kamu menyembah berhala. Oleh sebab itu agama kita tidaklah dapat diperdamaikan atau dipersatukan, "bagi kamu agama kamu, bagiku adalah agamaku pula". Tinggilah dinding yang membatas, dalamlah jurang di antara kita. ${ }^{155}$

Untuk lebih memantapkan keimanan dan keyakinan kita terhadap kebenaran Islam yang dibawa oleh nabi Muhammad 粠 dan mengetahui tuntunan yang benar berkenaan hubungan antar agama, penulis sajikan dalil-dalil al-Qur'an dan al-Hadits yang memberikan rambu-rambu kepada kita tentang bagaimana kita bersikap terhadapap saudara kita sesama manusia yang tidak seagama dengan yang kita anut.

\section{A. Dalil-dalil al-Qur'an}

1. Umat Islam diperbolehkan untuk bekerja sama dan bergaul dengan ummat agama lain dalam masalah-masalah yang berhubungan dengan masalah keduniaan. Hal demikian berdasarkan firman Allah dalam Surat al-Hujurat ayat 13:

Jilid 4, 648 .

${ }^{153}$ Ibnu Kathir, Tafsir al-Qur'an al- 'Adzim, (Madinah: Dar al-'Akidah, tt),

${ }^{154}$ Nama lengkapnya adalah Abu Abdillah Muhammad bin Ahmad al-Anshhari al-AlQurthubi, yang populer dengan al-Qurthubi.

${ }^{155}$ Lihat al-Qurthubi,Tafsir al-Qurthubi, (Beirut: Dar al-Kitab, 2001), Cet. IV, h. 206207. 
"Katakanlah: "Hai orang-orang kafir, aku tidak akan menyembah apa yang kamu sembah. dan kamu bukan penyembah Tuhan yang aku sembah. dan aku tidak pernah menjadi penyembah apa yang kamu sembah, dan kamu tidak pernah (pula) menjadi penyembah Tuhan yang aku sembah. untukmu agamamu, dan untukkulah, agamaku."

Dan juga firman-Nya di Surat al-Baqarah ayat 42:

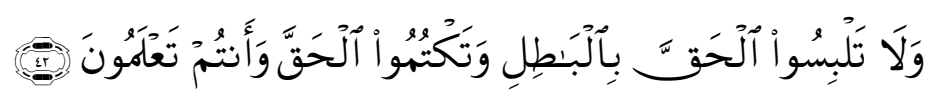

"dan janganlah kamu campur adukkan yang hak dengan yang bathil dan janganlah kamu sembunyikan yang hak itu[43], sedang kamu mengetahui".

3. Umat Islam tidak boleh memaksa umat lain untuk masuk agama Islam, karena sudah jelas antara Islam yang haq dan yang bathil. Hal ini berdasarkan firman-Nya dalam Surat al-Baqarah ayat 256:

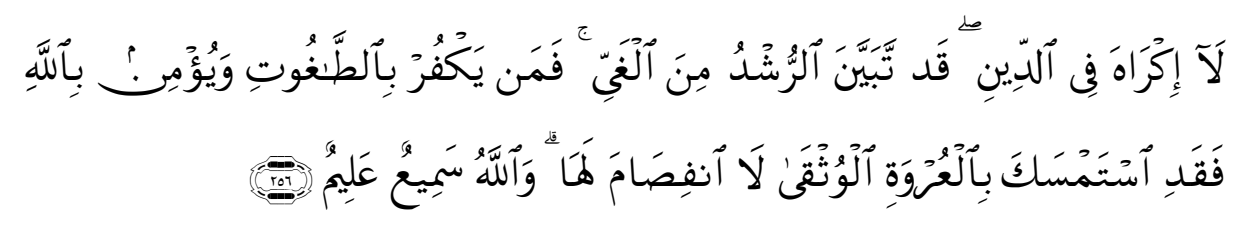

"Tidak ada paksaan untuk (memasuki) agama (Islam); Sesungguhnya telah jelas jalan yang benar daripada jalan yang sesat. karena itu Barangsiapa yang ingkar kepada Thaghut dan beriman kepada Allah, Maka Sesungguhnya ia telah berpegang kepada buhul tali yang Amat kuat yang tidak akan putus. dan Allah Maha mendengar lagi Maha mengetahui".

4. Umat Islam diwajibkan berdakwah kepada orang-orang kafir secara umum dan ahli kitab khususnya untuk memeluk agama Islam. Hal tersebut berdasarkan nash yang jelas dalam kitab dan sunnah. Sebagaimana firman-Nya dalam Surat Ali Imran ayat 64:

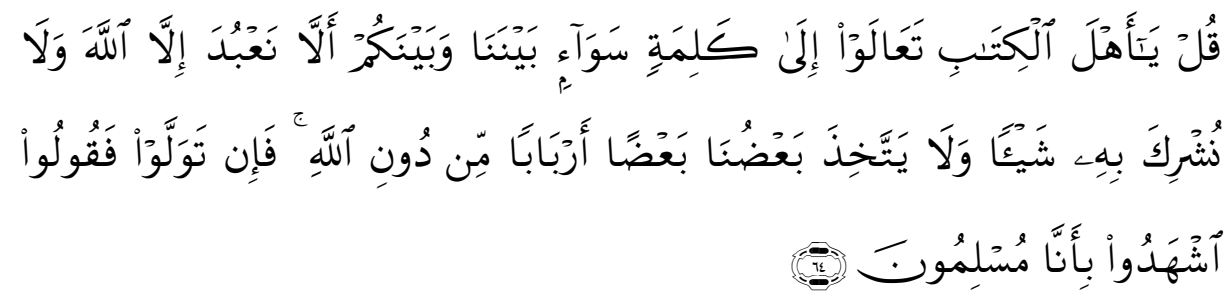


"Katakanlah: "Hai ahli Kitab, Marilah (berpegang) kepada suatu kalimat (ketetapan) yang tidak ada perselisihan antara Kami dan kamu, bahwa tidak kita sembah kecuali Allah dan tidak kita persekutukan Dia dengan sesuatupun dan tidak (pula) sebagian kita menjadikan sebagian yang lain sebagai Tuhan selain Allah". jika mereka berpaling Maka Katakanlah kepada mereka: "Saksikanlah, bahwa Kami adalah orang-orang yang berserah diri (kepada Allah)".

Dalam sebuah hadith yang diriwayatkan oleh imam Muslim, Rasulullah bersabda:

قال رسول الله صلى الله عليه وسلم, والذي نفس محمد بيده لايسمع بي أحد من هذه الأمة

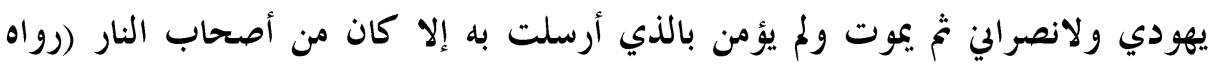

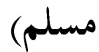

"Rasulullah bersabda, "Demi yang jiwaku berada di tangannya, tidak seorangpun dari umat manusia yang mendengarku; Yahudi maupun Nasrani, kemudian mati dan tidak beriman dengan ajaran yang aku bawa melainkan dia adalah penghuni neraka”. (HR. Muslim)

\section{B. Dalil as-Sunnah}

Di antara dalil as-Sunnah yang menjelaskan hubungan antara agama adalah:

1. Hadits yang diriwayatkan oleh salah seorang sahabat yang bernama Jabir bin Abdullah, Ia berkata, "suatu ketika nabi Muhammad 䊈 bangkit dari duduknya dan berdiri sebagai tanda kehormatan kepada seorang jenazah Yahudi yang diusung dan lewat dihadapannya. Melihat hal tersebut, para sahabat yang ada di sekitarnya berkomentar, "Ya Rasulullah, yang berlalu itu adalah jenazah Yahudi."Rasul menjawab: "Apakah dia bukan sorang manusia?".

2. Hadith dari Aisyah , di mana ia berkata, "Bahwa Rasulullah pernah membeli makanan dari orang Yahudi dan beliau menggadaikan baju besi'". (HR. Bukhari dan Muslim).

3. Sejarah Islam mencatat dengan tinta emas, tentang akhlak para pemimpinnya yang sangat adil dalam menerapkan hukum (tanpa pandang bulu) meskipun mereka seorang penguasa. Sebagaimana pristiwa Ali dengan orang Yahudi dalam kasus baju besi, Umar dengan rakyatnya seorang Yahudi yang miskin. Mereka adalah para pemimpin yang sangat paham terhadap Islam. 
Beberapa riwayat di atas, meski sederhana tetapi paling tidak memuat dua panduan utama dalam berinteraksi di tengah keragaman etnik dan agama.

Pertama, dari ekspresi Rasulullah "apakah dia bukan seorang manusia", dapat dipahami bahwa interaksi, pergaulan penghormatan di antara sesame manusia, ternyata didasarkan kepada prinsip 'kemanusiaan'. Meskipun entik dan agama berbeda tetapi perbedaan itu tidak dijadikan untuk dapat hidup bersama secara harmonis. Bukankah yang dihormati Rasulullah dalam riwayat di atas seorang Yahudi, bahkan sudah tak bernyawa lagi.

Kedua, interaksi dalam keragaman suku, etnik, dan agama tidaklah terbatas saling menghormati satu sama lain, tetapi juga saling membantu dalam urusan social dan ekonomi, seperti yang tergambar dari mu'amalah Nabi dengan orang Yahudi.

Dalam Islam tidak ada halangan untuk saling membantu di antara umat yang berbeda selama mereka orang-orang kafir tidak mengganggu dan memerangi ummat Islam, sebagaima dijelaskan dalam Surat al-Mutahanah ayat 8 , yang berbunyi:

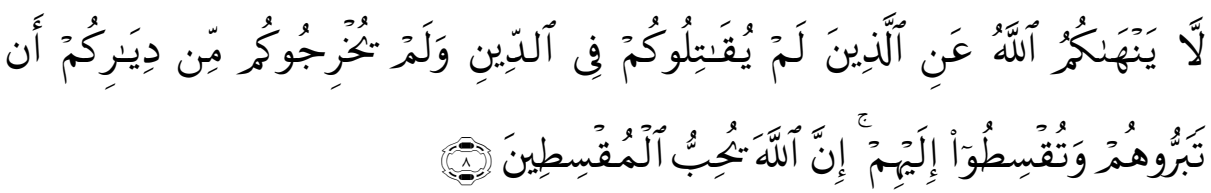

"Allah tidak melarang kamu untuk berbuat baik dan Berlaku adil terhadap orang-orang yang tiada memerangimu karena agama dan tidak (pula) mengusir kamu dari negerimu. Sesungguhnya Allah menyukai orang-orang yang Berlaku adil",

Bukan sebuah kebetulan apabila hari ini kita menyaksikan sebuah pemandangan keharmonisan antar agama di bumi indonesia khususnya umat Islam, boleh jadi hal itu merupakan pengejawantahan mereka ummat Islam terhadap rambu-rambu yang ada dalam ajaran Islam. Meskipun demikian, kita tidak menafikan adanya pristiwapristiwa berbau syara masih terjadi di bumi Indonesia. Allahu A'lam 


\section{Kesimpulan}

Dari uraian tulisan di atas, maka dapat penulis simpulkan sebagai berikut:

Pertama, sebagai seorang Muslim, kita harus mengimani bahwa agama para nabi adalah Islam, bukan yang lainnya dan meyakini tidak ada agama yang diterima di sisi-Nya kecuali Islam.

Kedua, Keterangan-keterangan di atas memberi gambaran bahwa agama adalah masalah yang tidak bisa ditawar-tawar lagi, apalagi berganti. Kemajemukan agama tidak menghalangi untuk hidup bersama, berdampingan secara damai dan aman. Adanya saling pengertian dan pemahaman yang dalam akan keberadaan masingmasing menjadi modal dasar yang sangat menentukan. Pengalamanpengalaman Nabi dan para pemimpin Islam di atas mengandung dimensi moral dan etis.

Ketiga, Di antara dimensi moral dan etis agama-agama adalah saling menghormati dan menghargai agama/pemeluk agama lain. Jika masing-masing pemeluk agama memegang moralitas dan etikanya masing-masing, maka kerukunan, perdamaian dan persaudaraan bisa terwujud.

Demikian pemaparan tulisan tentang konsep hubungan antar agama, semoga menjadi amal shalih bagi penulis dan dapat memberikan manfaat bagi para pembaca semua. 


\section{Daftar Pustaka}

Ali, A., Mukti, Ilmu Perbandingan Agama, Dialog, Dakwah dan Misi, dalam Burhanudin Daja dan Herman Leonard Beck , Ilmu Perbandingan Agama di Indonesia dan Belanda, (Jakarta: INIS 1992).

Bakr Abu Zaid "Ibthal Nadzariyah al-Khalath Bainal Islam wa Ghairihi minal Adyan, Terjemahan, Propaganda Sesat Penyatuan Agama, (Jakarta; Darrul Haq, 2002).

Abdul Aziz, Shaleh, Syarah Kitab al-Furqan Baina Auliya al-Rahman wa Auliya al-Syaithan, edisi Indonesia: Catatan-catatan Ibnu Taimiyah Menembus Batas kewalian, Penerjemah: Azhar Khalid, (Jakarta: Akbar, 2008), Cet. I,

Deedat, Ahmad, dan Wasian, Abdullah, dalam bukunya, Kata Bibel tentang Muhammad, (Jakarta: Pustaka Da'i, 1993), cet. II.

Efendi, Djohan, Dialog Antar Agama: Bisakah Melahirkan Teologi Kerukunan? Dalam Majalah Prisma 5, Juni 1978, h. 16. Lihat juga Djohan Efendi, Kemusliman dan Kemajemukan Agama, dalam Th. Sumarthana dkk, Dialog: Kritik dan Identitas Agama.

Husaini, Adian, Tinjauan Historis Konflik Yahudi, Kristen, Islam, (Jakarta: GIP, 2004), Cet. I.

http://www.muslimdaily.net/artikel/studiislam/pluralisme-agamadalam-pandangan-islam.html.diakses tanggal 20 Oktober 2017

Hakami, Ahmad, 200 Su'al wa al-Jawab Fil al-'Aqidati al-Islamiyyah, Edisi Indonesia, 222 Kunci Akidah yang Lurus, Penerjemah: Moh. Asror Yusuf, (Jakarta: Mustaqim, 2004), Cet. II.

Hamid, Abdul Kisyk, Dialog Haq dan Bathil, (Solo: Pustaka Mantiq, 1992), Cet. II.

Husaini, Adian, Virus Liberalisme di Perguruan Tinggi Islam, (Jakarta: Gema Insani Perss, 2009), Cet. I.

Ibnu Katsir, Tafsir al-Qur'an al- 'Adzim, (Madinah: Dar al-'Akidah, tt), Jilid 4.

Lajnah Ilmiyyah Hasmi, al-Shiratul al-Mustaqim, (Bogor: Putaka MIM, 2007), Cet. I. 
L. Esposito, John Islam: The Straight Path, Islam Warna Warni: Ragam Ekspresi Menuju "Jalan Lurus", Arif Maftuhin, (Jakarta: Paramadina, 2004), Cet. I.

Majid, Nurcholis, Beberapa Renungan tentang Kehidupan Keagamaan untuk Generasi Mendatang, dalam Jurnal Ulum al-Qur'an, No. 1, Vol. IV, Th. 1993.

Lewis, Bernand, The Jews of Islam, Edidsi Indonesia, Yahudi-Yahudi Islam, Penerjemah: M. Sadat Ismail, (Jakarta: Nizam Press, 2001), Cet.I.

Al-Qurthubi, Tafsir al-Qurthubii, (Beirut: Dar al-Kitab, 2001), Cet. IV. 